THE LANGUAGE OF LITERATURE

General Editor: N. F. Blake

Professor of English Language and Linguistics

University of Sheffield 


\section{THE LANGUAGE OF LITERATURE}

\section{General Editor: N. F. Blake}

Professor of English Language and Linguistics,

University of Sheffield

\section{Published titles}

An Introduction to the Language of Literature

The Language of Shakespeare

The Language of Wordsworth and Coleridge

The Language of Irish Literature

The Language of Drama

The Language of the Metaphysical Poets

The Language of James Joyce

The Language of Twentieth-Century Poetry

The Language of George Orwell

The Language of Old and Middle English Poetry
N. F. Blake
N. F. Blake
Frances Austin
Loreto Todd
David Birch
Frances Austin
Katie Wales
Lesley Jeffries
Roger Fowler
G. A. Lester

\section{Series Standing Order (The Language of Literature)}

If you would like to receive future titles in this series as they are published, you can make use of our standing order facility. To place a standing order please contact your bookseller or, in case of difficulty, write to us at the address below with your name and address and the name of the series. Please state with which title you wish to begin your standing order. (If you live outside the United Kingdom we may not have the rights for your area, in which case we will forward your order to the publisher concerned.)

Customer Services Department, Macmillan Distribution Ltd Houndmills, Basingstoke, Hampshire RG21 6XS, England 


\section{The Language of Twentieth-Century Poetry}

LESLEY JEFFRIES 
All rights reserved. No reproduction. copy or transmission of this publication may be made without written permission.

No paragraph of this publication may be reproduced. copied or transmitted save with written permission or in accordance with the provisions of the Copyright. Designs and Patents Act 1988. or under the terms of any licence permitting limited copying issued by the Copyright Licensing Agency, 9() Tottenham Court Road. London WIP 9HE.

Any person who does any unauthorised act in relation to this publication may be liable to criminal prosecution and civil claims for damages.

First published 1993 by

THE MACMILLAN PRESS LTD

Houndmills. Basingstoke. Hampshire RG21 2XS

and London

Companies and representatives

throughout the world

ISBN 978-0-333-45937-9 ISBN 978-1-349-23000-6 (eBook)

DOI 10.1007/978-1-349-23000-6

A catalogue record for this book is available

from the British Library

Typeset by Florencetype Ltd. Kewstoke. Avon 


\section{Contents}

Acknowledgements vii

Pronunciation Guide $\quad$ ix

Introduction 1

1 Twentieth-Century Poetry in English 4

2 The Influence of the Spoken Language 22

3 The Sound of Twentieth-Century Poetry 39

4 Word Forms and Combinations 57

5 Word-Choice and Meaning 79

6 Grammatical Structure 96

7 Textual Cohesion and Orientation 114

8 Examples of Analysis 134

Notes $\quad 149$

Glossary $\quad 151$

References: Poetry 164

$\begin{array}{lr}\text { Bibliography } & 170\end{array}$

$\begin{array}{ll}\text { Index } & 173\end{array}$ 
To Joan and Rod Jeffries, with love 


\section{Acknowledgements}

I should like to express my appreciation to all my family and my friends and colleagues who have given me moral and practical support while this book was being written. I have received particular help on some details from Loreto Todd and Lynette Hunter of the School of English, University of Leeds, from Paul Bembridge of the School of Music and Humanities. University of Huddersfield, and from the series editor. Norman Blake, of Sheffield University. I am very grateful for this help, but remain responsible for any errors of fact or interpretation $I$ have included. I am indebted to Dave Webb who has given this project considerable amounts of time and patience and gave invaluable help in finding lost files. Finally I should thank Sam and Ella whose patience in finding that they have no clean clothes to wear - again - has been exemplary.

The author and publishers wish to thank the following for permission to use copyright material:

André Deutsch Ltd for extracts from 'Canticle for Good Friday' from Collected Poems by Geoffrey Hill (1962); Faber \& Faber Ltd for 'Broadcast' and extracts from 'And Bad as a Mile', 'Talking in Bed' and 'Water' from The Whitsun Weddings by Philip Larkin (1964); with Alfred A. Knopf. Inc. for 'A Hairline Fracture' from The Kingfisher by Amy Clampitt (1983), copyright (.) 1983 by Amy Clampitt; extracts from 'XXVII' and 'VI' from The North Ship by Ted Hughes (1966), and 'The Lake in the Park' from The Collected Poems of Louis MacNeice, ed. W.H. Auden (1964); Claire Harris for an extract from 'The Conception of Winter' from The Conception of Winter. Williams Wallace Publishers (1989): 
A.M. Heath \& Company Ltd on behalf of the author and Alfred A. Knopf, Inc., for extracts from 'The Women in the Ordinary' and 'In the Men's Room(s)' by Marge Piercy from Circles in the Water: Selected Poems of Marge Piercy, Alfred A. Knopf, Inc. Copyright (1) 1972, 1973, 1982 by Marge Piercy and Middlemarsh Inc.; and 'Mornings in Various Years' from Stone, Paper, Knife by Marge Piercy, Pandora and Alfred A. Knopf. Inc. Copyright (1) 1983 by Marge Piercy and Middlemarsh Inc.: Peters Fraser \& Dunlop Group Ltd on behalf of the author for 'The Freedom Won by War for Women' from Unplayed Music by Carol Rumens (1982). Secker \& Warburg: Gwydion Thomas for an extract from 'Evans' by R.S. Thomas (1962), William Collins Sons and Co.; Myfannwy Thomas for 'The Owl' by Edward Thomas, HeathStubbs (1953).

Every effort has been made to trace all the copyright holders, but if any have been inadvertently overlooked the publishers will be pleased to make the necessary arrangement at the first opportunity. 


\section{Pronunciation Guide}

There are a small number of phonemic symbols used in this book. to indicate sounds more accurately than is possible by orthography. Those symbols which might be unfamiliar to the reader, or might have different phonemic values to normal. are represented here.

\section{CONSONANTS}

Most of the consonantal symbols have predictable pronunciations. The following do not:

$/ \mathbf{\theta} /$ as in think

$/ \mathrm{d} /$ as in there

$/ \mathrm{J} /$ as in ship

$13 /$ as in garage

$/ \mathrm{g} /$ as in church

$/ \mathrm{d} /$ as in judge

$/ \mathrm{J} /$ as in your

$/ \mathrm{n} /$ as in sing

\section{VOWELS}

The written vowels have many different pronunciations in English. The following symbols, relating to an RP (Received Pronunciation) accent, are used here:

/1/ as in bit

/i:/ as in feet

/e/ as in bed 
$X$ THE LANGUAGE OF TWENTIETH-CENTURY POETRY

$/ a /$ as in bad

/a:/ as in bath

$\mathrm{I} / \mathrm{as}$ in cup

$10 /$ as in put

$/ \mathrm{u}: /$ as in food

/a/ as in unstressed the

/ail as in bright

/ei/ as in fate

$/ \mathrm{au} / \mathrm{as}$ in foul

/e3/ as in fair

$1 / 13 /$ as in fear 